\title{
Seismic reflection profiling across the Itoigawa-Shizuoka Tectonic Line at Matsumoto, Central Japan
}

\author{
Yasutaka Ikeda ${ }^{1}$, Takaya Iwasaki ${ }^{2}$, Hiroshi Sato ${ }^{2}$, Nobuhisa Matsuta $^{2}$, and Takeshi Kozawa ${ }^{3}$ \\ ${ }^{1}$ Department of Earth and Planetary Science, University of Tokyo, 7-3-1 Hongo, Bunkyo-ku, Tokyo 113-0033, Japan \\ ${ }^{2}$ Earthquake Research Institute, University of Tokyo, 1-1-1 Yayoi, Bunkyo-ku, Tokyo 113-0032, Japan \\ ${ }^{3}$ JGI Inc., 1-5-21 Otsuka, Bunkyo-ku, Tokyo 112-0012, Japan
}

(Received April 27, 2004; Revised October 1, 2004; Accepted December 7, 2004)

\begin{abstract}
The Itoigawa-Shizuoka Tectonic Line (ISTL) in Central Japan is a fault zone with a very high slip rate during Pliocene-Quaternary time. Our seismic reflection and gravity surveys across the northern segment of the ISTL at Matsumoto have revealed its geometry to a depth of $\sim 5 \mathrm{~km}$. The fault plane was found to be of fairly low angle, in spite of the surface geologic observations that late Quaternary movements on this fault zone are dominantly strike slip. Partitioning of slip is taking place between the East Boundary Fault (thrust) and the Gofukuji Fault (left-slip), which constitute the fault zone and are parallel to and a few $\mathrm{km}$ apart from each other. However, these two faults are found to merge down-dip at a depth as shallow as $1.5 \mathrm{~km}$ below the surface. The geometry of the ISTL is significantly discordant with the orientation of the maximum shear stress acting regionally on Central Japan, indicating that the fault plane is of very low strength.
\end{abstract}

Key words: Itoigawa-Shizuoka Tectonic Line, active fault, seismic reflection profiling, slip partitioning, oblique slip, tectonic inversion.

\section{Introduction}

Central Japan is characterized by densely developed active faults. The Itoigawa-Shizuoka Tectonic Line (ISTL), a fault zone about $250 \mathrm{~km}$ long and several $\mathrm{km}$ wide, is the most active among the faults in terms of long-term slip rates (e.g., Ikeda and Yonekura, 1986) and recurrence intervals of faulting events (e.g., Okumura, 2001). Ongoing crustal activity has been detected by recent GPS measurements; Sagiya et al. (2002) revealed horizontal shortening at a rate as high as $0.3 \mu$ strain/yr across the ISTL. Therefore, the ISTL has drawn much interest not only from a geologic viewpoint but also from a viewpoint of earthquakedisaster prevention.

The ISTL is divided into two segments at the north part of Suwa Lake (Fig. 1). Existing data suggest that the segment north of Suwa Lake (which will be referred to hereafter as the northern segment) is inclined moderately to gently toward the east (Hagiwara, 1967; Ikami et al., 1986; Okubo et al., 2000), whereas the segment south of Suwa Lake (the southern segment) dips toward the west (Kumamoto and Ikeda, 1993; Ikeda and Kumamoto, 1994). Therefore a significant boundary of rupture segments may exist at or near Suwa Lake. To reveal the structure and behavior of this segment boundary, a three-year research project has started in 2002. As a part of this project we made seismic reflection and gravity surveys to the north and south of the segment boundary in 2002 and 2003 , respectively.

In this paper we report preliminary results of the seis-

Copy right(c) The Society of Geomagnetism and Earth, Planetary and Space Sciences (SGEPSS); The Seismological Society of Japan; The Volcanological Society of Japan; The Geodetic Society of Japan; The Japanese Society for Planetary Sciences; TERRAPUB. mic reflection and gravity surveys that were carried out in 2002 across the northern segment of the ISTL at Matsumoto about $20 \mathrm{~km}$ northwest of Suwa Lake. The sense of slip on the northern segment, in the study area, is dominantly strike slip with a smaller component of thrust slip (e.g., Ikeda and Yonekura, 1986); partitioning of slip takes place within a narrow fault zone less than a few kilometers wide (Matsuta, 2002). Thus, the present study will give an observational constraint on the mechanism of slip partitioning on an inclined fault, and we discuss some implications for active tectonics of central Japan.

\section{Geologic Setting}

The northern segment of the ISTL is located at the western margin of the Northern Fossa Magna, which was a rifted basin (half graben) formed at the final stage (ca. 17 Ma) of back-arc spreading of the Japan Sea (Sato et al., 2004). Sato and Ikeda (1999a, b) and Sato et al. (2004) interpreted that the master fault that formed the Northern Fossa Magna basin was an east-dipping, low-angle normal fault, on which a large amount of slip (>40 km) occurred in middle Miocene time. This rifted basin is filled with a thick pile of sediments and volcanic rocks with a total thickness of more than $6 \mathrm{~km}$ (Yano, 1986; Kato, 1992).

Since early Pliocene time, this low-angle fault has reactivated as an oblique-slip (thrust plus left slip) fault, due to the change in regional stress fields from tension to EW compression (Sato and Ikeda, 1999a, 1999b; Sato et al., 2004). The reactivated fault has progressively propagated up-dip (westward) along the base of the Miocene basin fills, so that almost the whole part of the basin is now on the hanging wall side and hence is subjected to compressive de- 


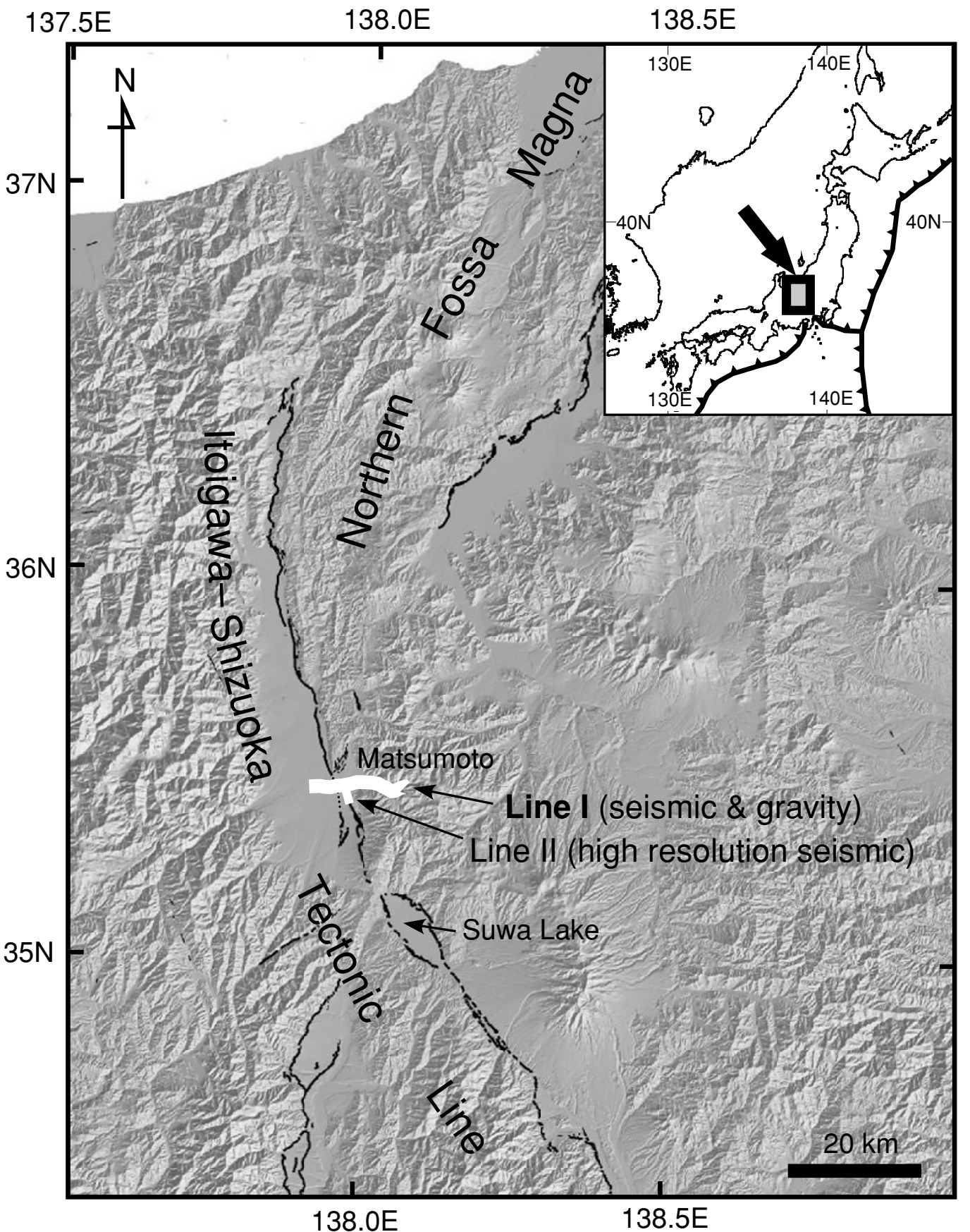

Fig. 1. A map showing regional settings of the Itoigawa-Shizuoka Tectonic Line. Solid, black lines indicate active faults (after Ikeda et al., 2002).

formation. The ISTL is interpreted as the deformation front of this progressive deformation.

The ISTL in the Matsumoto area consists of two active fault strands (Figs. 1 and 2): one is the East Boundary Fault of the Matsumoto Basin, which is inferred to be an eastdipping thrust fault separating Miocene rocks on the east from post-reactivation sediments of Pliocene-Quaternary age on the west; the other is the Gofukuji fault, which is parallel to and a few $\mathrm{km}$ to the east of the East Boundary Fault. The Gofukuji Fault, however, is almost purely strike slip; left-lateral offsets of alluvial fan of late Quaternary age yield a slip rate as high as $8.6 \pm 1.5 \mathrm{~mm} / \mathrm{yr}$ (Fig. 3; Ikeda and Yonekura, 1986), which rate is much higher than the rate of thrust slip on the East Boundary Fault of the Matsumoto
Basin (Ikeda et al., 2002).

Although existing data including surface geology, gravity anomalies (e.g., Hagiwara et al., 1986; Okubo et al., 2000), seismic refraction experiments (e.g., Ikami et al., 1986), and magnetotelluric measurements (Ogawa et al., 2002) have suggested that the ISTL dips gently or moderately to the east, the sense of slip as a whole is dominantly strike slip.

\section{Seismic and Gravity Surveys}

Seismic reflection profiling and gravity measurements were made along a $14 \mathrm{~km}$ line (Line I in Figs. 1 and 2), which goes through the downtown Matsumoto (at distances 3.5-7 km from the west end of Line I; Figs. 1 and 2). Three 


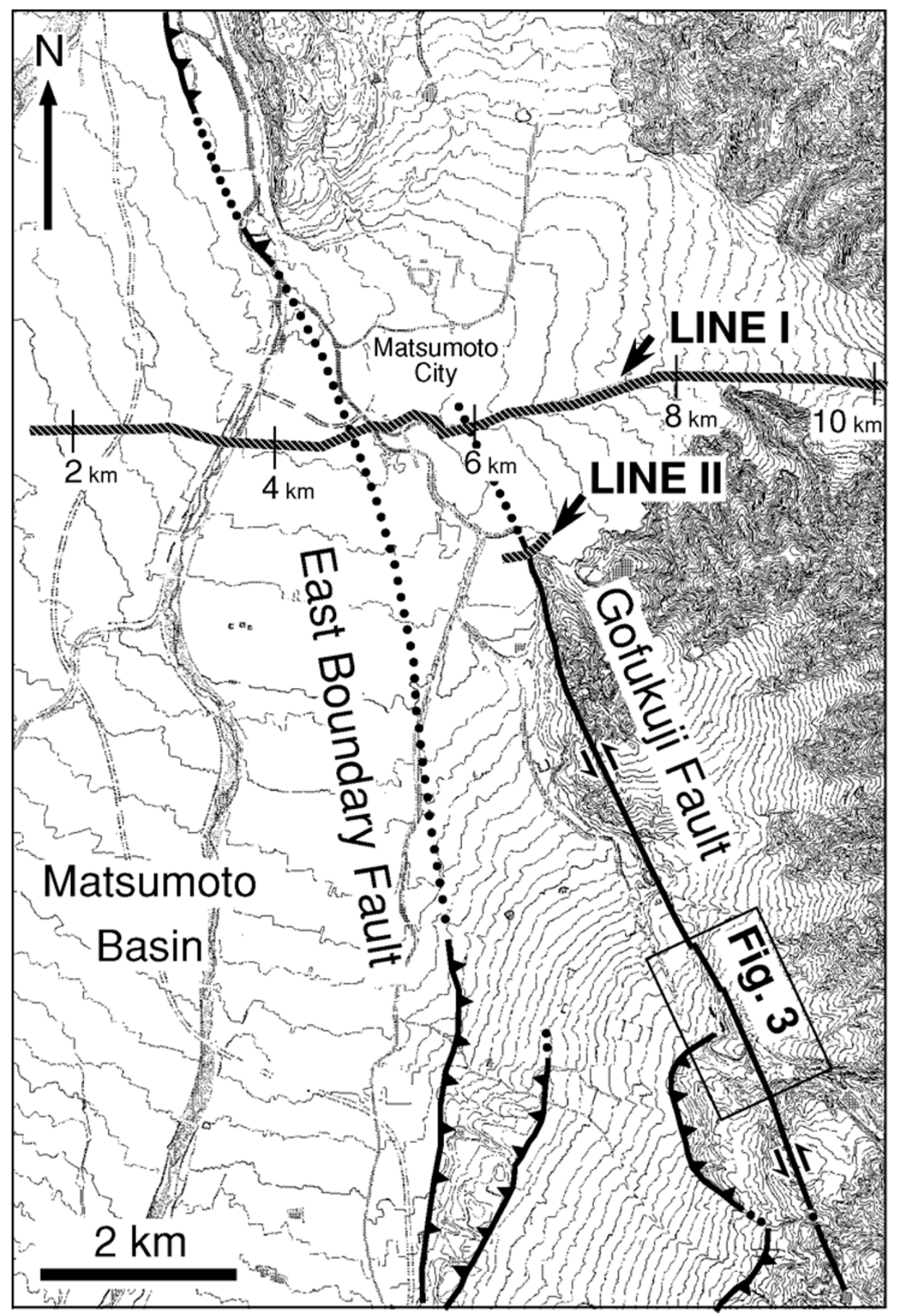

Fig. 2. A map showing the location of seismic and gravity survey lines across the Itoigawa-Shizuoka Tectonic Line. Solid, black lines indicate active faults (dotted where inferred or approximately located; with teeth on hanging-wall side). Topographic contour lines are at 10-meter intervals.

high energy vibroseis trucks were used to generate source signals at $100 \mathrm{~m}$ shot intervals along Line I, except the downtown area, where mainly a small vibrator (minivib) was used because of environmental concerns. 661 receiver stations were deployed at $25 \mathrm{~m}$ intervals, except for a $3.5 \mathrm{~km}$ long portion in the vicinity of the fault zone, where receiver stations were set at $12.5 \mathrm{~m}$ intervals and shots were made at $12.5 \mathrm{~m}$ intervals, in order to image the shallow structure of the fault zone at higher resolution.

Gravity measurements were also made at about 100meter intervals along Line I and its westward and eastward extensions by using a LaCoste \& Romberg gravity meter.
The height of each gravity station was measured by leveling.

A very-high-resolution seismic reflection survey was also carried out using a small vibrator (Minivib) along a $500 \mathrm{~m}$ line (Line II; Fig. 2) across the Gofukuji Fault, in order to determine the detailed structure of the fault to a depth of a few hundred meters. 100 receiver stations were deployed at $5 \mathrm{~m}$ intervals, and a $15 \mathrm{~m}$ shot spacing was used.

\section{Results}

A very strong, gently east-dipping reflector exists near the west end of Line I at a depth of 1-2 km below the mean 

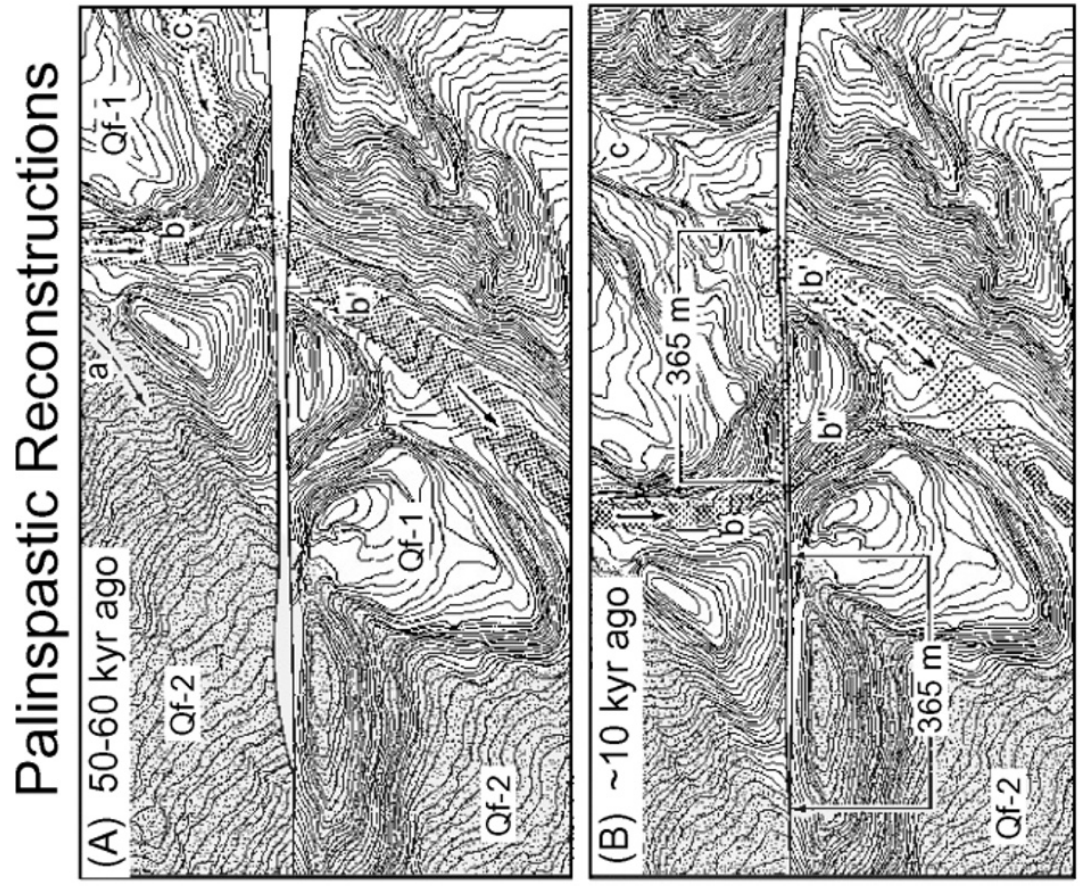

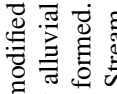

영

을

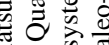

$\sum_{0}^{0}$

E 응

은

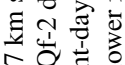

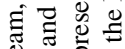

至要要

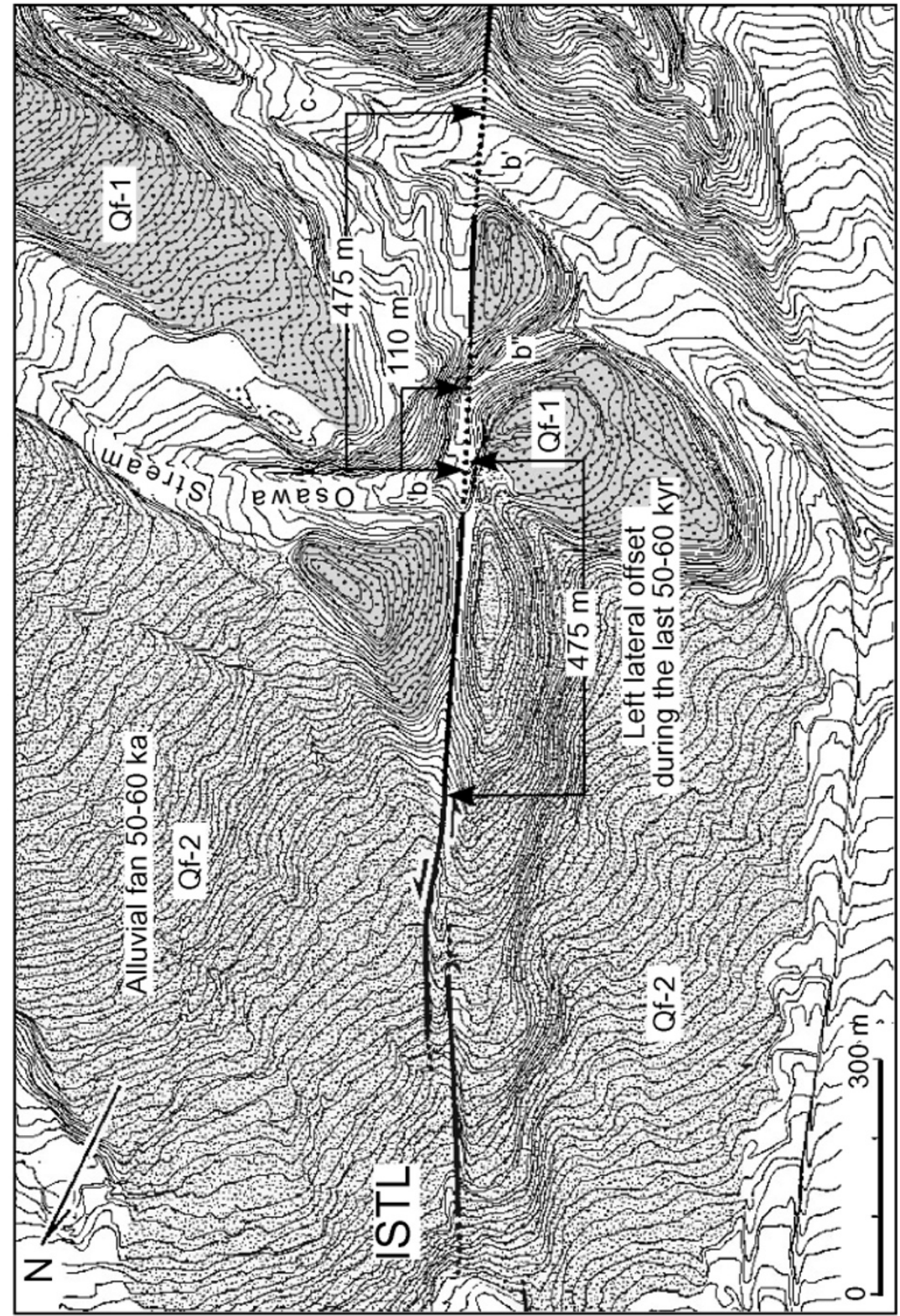

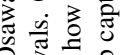

宛

흘

䒠司

굴

ㅇㅇㅇ

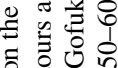

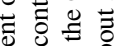

氙

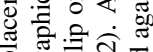

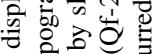

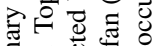

흥.

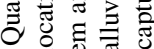

总 总

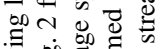

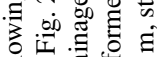

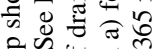

है उै ठे

영

응 ह

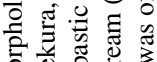

范范苛

总政

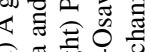

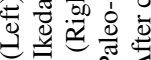

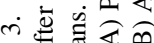

这 


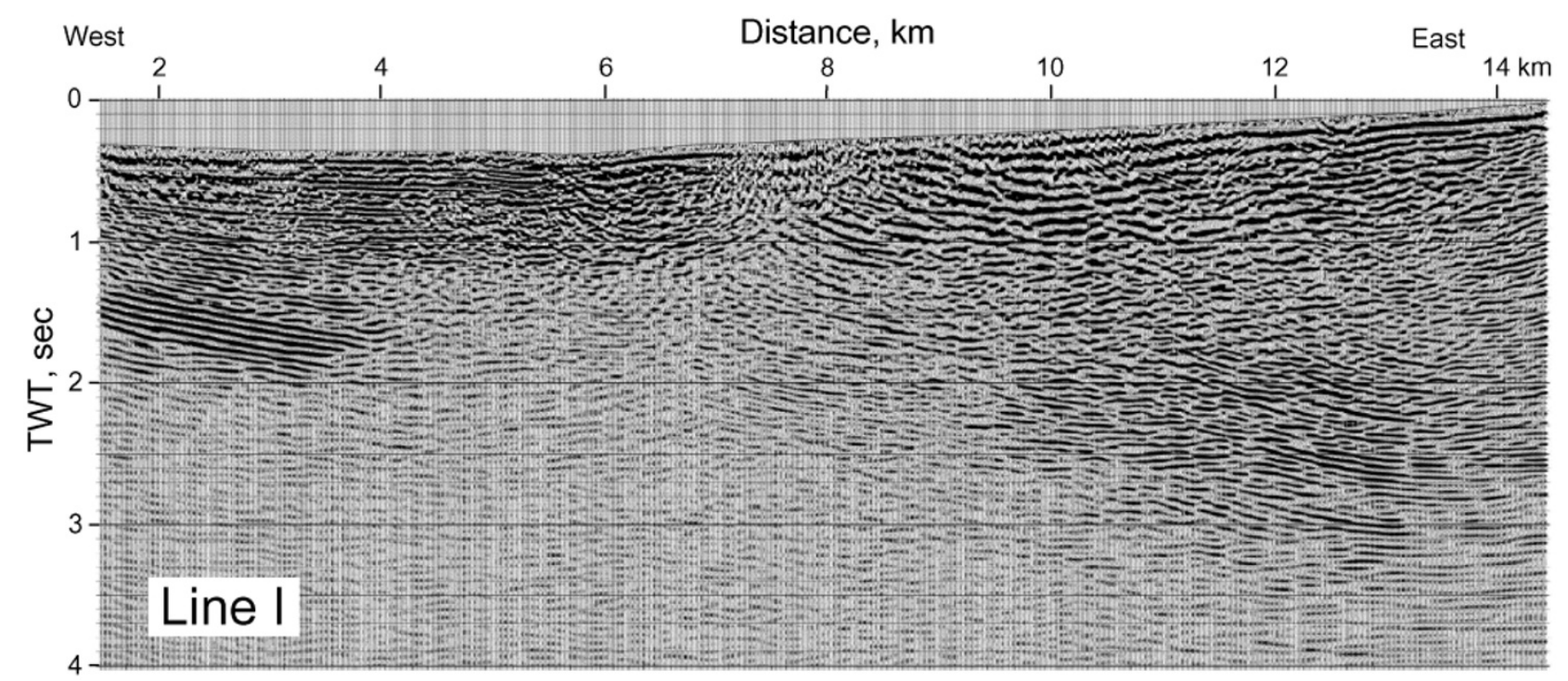

Fig. 4. Migrated time section along Line I across the Itoigawa-Shizuoka Tectonic Line. See Figs. 1 and 2 for location.

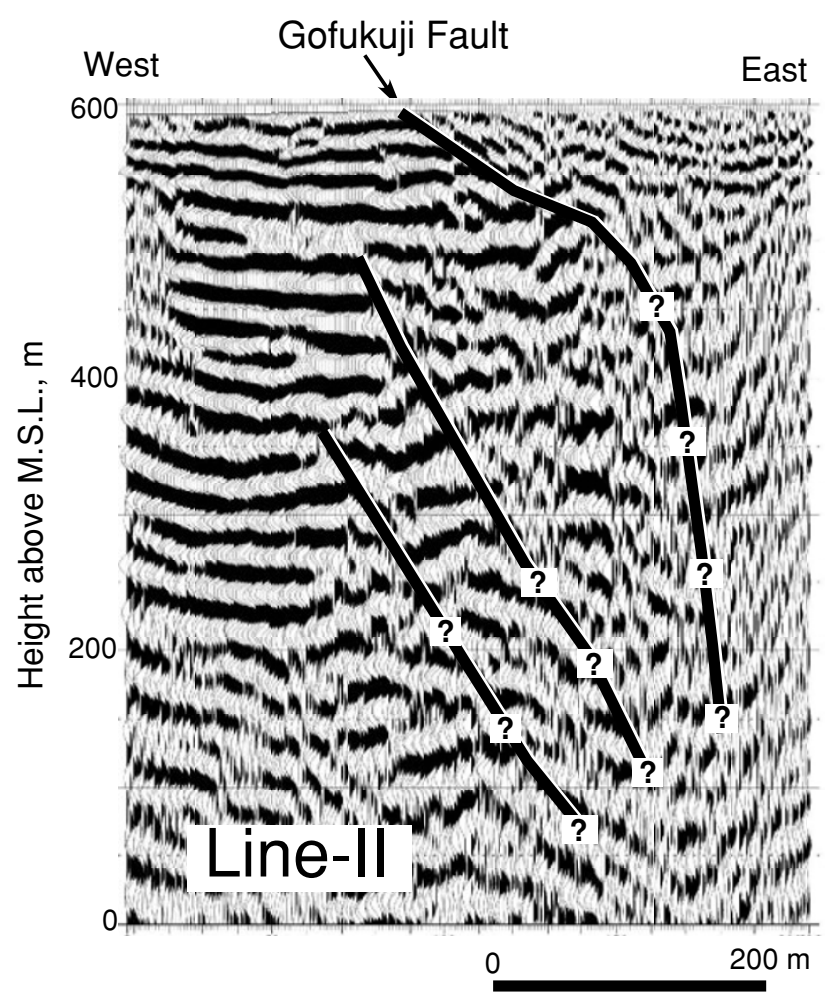

Fig. 5. Depth-converted, migrated section showing the result of very shallow seismic reflection profiling along Line II across the Gofukuji Fault. Interpreted faults are indicated by solid lines (with question marks where inferred).

sea level (Figs. 4 and 6). This reflector is traceable eastward to the point about $4 \mathrm{~km}$ from the east end of Line I; it is interpreted as an unconformity between pre-Tertiary rocks and young basin fills.

A set of thinly layered, sub-horizontal reflectors exists above the strong reflector near the west end. This unit has low interval velocities ranging from 1.8 to $2.9 \mathrm{~km} / \mathrm{sec}$, and hence is interpreted as fluvial deposits derived mainly from the Hida Mountains located to the west in PlioceneQuaternary time. This unit thickens toward the east to form a sedimentary wedge, and terminates abruptly against a rock body with complex seismic signatures at the distance of $4.7 \mathrm{~km}$ from the west end, where the surface trace of the East Boundary Fault is estimated. This fault can be recognized as the abrupt termination of reflectors down to a depth of about $1 \mathrm{~km}$, and is traceable further down-dip as a series of strong (but discontinuous) reflectors to a depth of $3.5 \mathrm{~km}$ at a distance about $12-13 \mathrm{~km}$ (Figs. 4 and 6).

The upper half of the rock unit on the hanging wall side of the East Boundary Fault is reflective with interval velocities ranging from 2.9 to $4.5 \mathrm{~km} / \mathrm{sec}$, whereas the lower half is rather transparent with higher velocities. It is inferred 


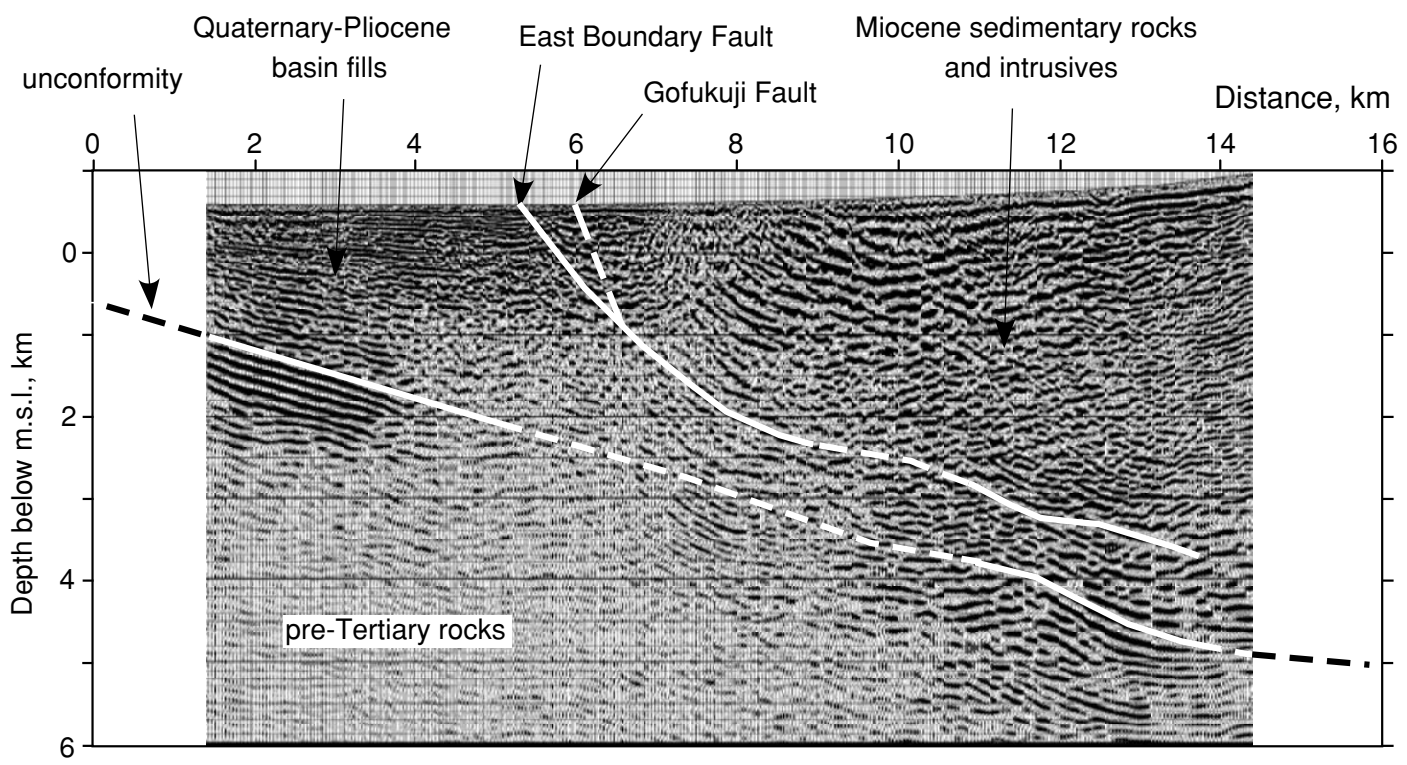

Fig. 6. Interpreted, migrated depth section along Line I across the Itoigawa-Shizuoka Tectonic Line.
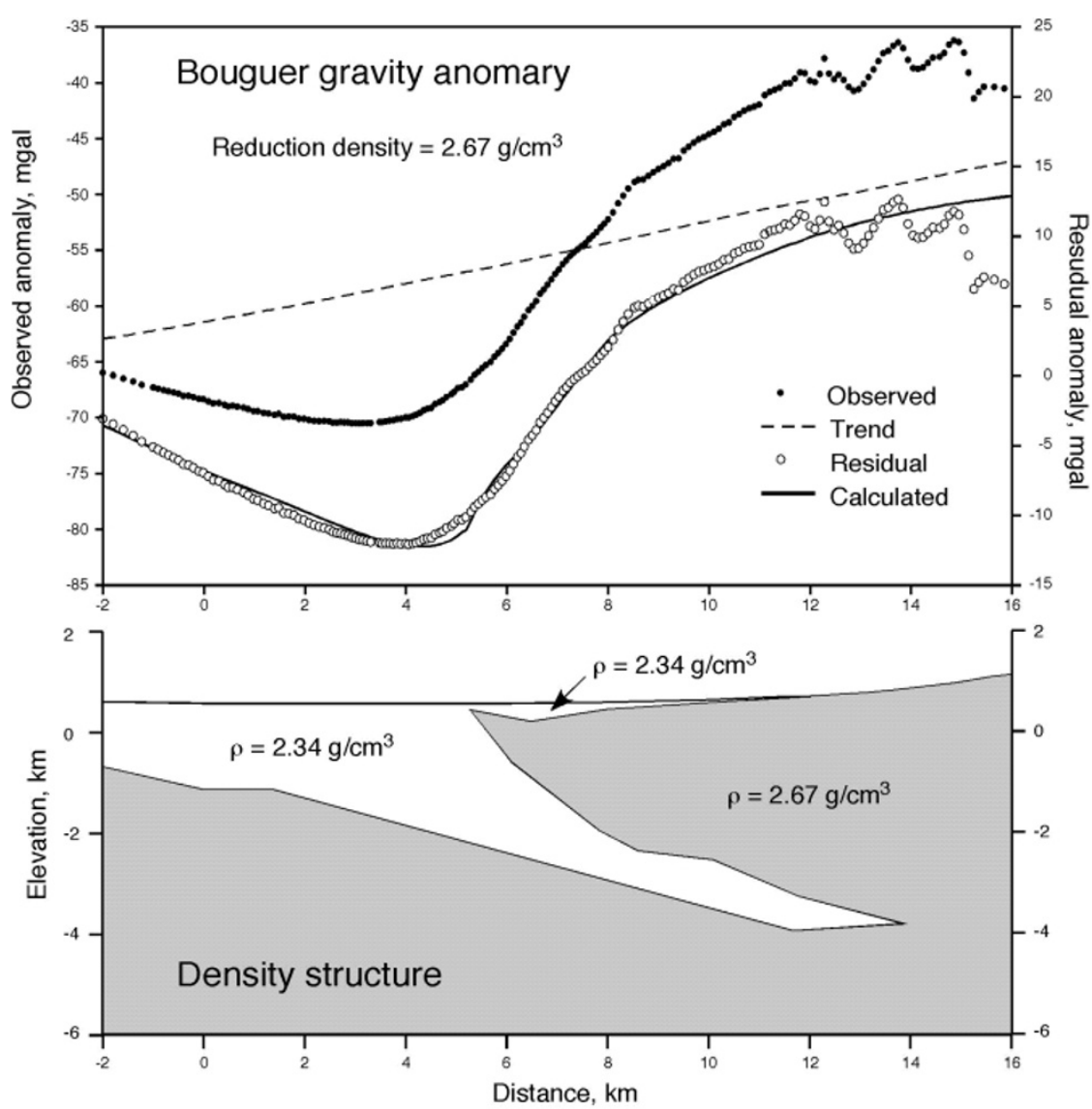

Fig. 7. (Top) Gravity anomaly along Line I across the Itoigawa-Shizuoka Tectonic Line. The residual gravity anomaly (open circles) is the difference between the observed Bouguer anomaly (closed circles) and the long-wavelength gravity trend (dashed line), which is caused mainly by varying depths of Moho and subducting oceanic slabs in the asthenosphere (Furuse and Kono, 2003; Kono, 2003). Computed gravity anomaly (solid line) based on the density structure model is shown by solid line. (Bottom) Two-dimensional density structure model along Line I.

from surface geology that the upper half consists mainly of sandstone-mudstone alternation with andesite sills of middle to late Miocene age, and the lower half consists mainly of middle Miocene volcaniclastics and diorite intrusives. This rock unit shows a synclinal structure with its axis at a distance of $10 \mathrm{~km}$. Reflectors within this unit are parallel to the listric shape of the East Boundary Fault, suggesting that the fault was a bedding slip fault at depth and at least 5 $6 \mathrm{~km}$ of thrust slip is necessary to form the present geologic structure. 
A complex pattern at distances from 7 to $8 \mathrm{~km}$ near the surface is due partly to low signal-to-noise ratio caused by heavy traffics. However, transmitted vibroseis signals from within this zone were strongly absorbed, indicating that a fracture zone might exist here.

The Gofukuji Fault is not visible in the seismic section of Line I. This fault is, however, clearly imaged in the very-shallow seismic profile along Line II (Fig. 5). It dips about 40 degrees to the east at shallow depths and seems to become steeper down-dip. If this dip angle is applied to the Line I profile, then the Gofukuji Fault merges into the East Boundary Fault at a depth of about $1.5 \mathrm{~km}$ below the surface (Fig. 6).

Overall geometry of the ISTL estimated here is also evidenced by Bouguer gravity anomalies. We constructed a two-dimensional, two-layered density structure model (Fig. 7). In this model, the configuration of the sedimentary wedge, except its westernmost and easternmost (deepest) parts, is fixed in accordance with the interpretation of the seismic profile (Fig. 6). A thin surface layer is also introduced to represents late Quaternary alluvium covering the hanging wall side of the East Boundary Fault. By using a non-linear inversion method, we determined the density contrast and the geometry of layer boundaries where unconstrained by the seismic profile. Fitness of calculated gravity values to the observed values is good except for the easternmost part. The density structure model thus obtained indicates that (1) a significant density contrast exists at the East Boundary Fault, and (2) the low-density sedimentary wedge of Pliocene-Quaternary age is to be thrust under the Miocene rocks for at least $4-6 \mathrm{~km}$.

\section{Discussions and Conclusion}

Our seismic profiling and gravity measurements across the ISTL have revealed that dominantly strike-slip faulting is taking place on a low-angle fault plane. Partitioning of slip does occur in association with this low-angle faulting, but is only a shallow phenomenon; the East Boundary Fault (thrust) and the Gofukuji Fault (left-slip) merges down-dip at a depth as shallow as $1.5 \mathrm{~km}$ below the surface.

The geometry of the ISTL is significantly discordant with the orientation of the maximum shear stress acting regionally on Central Japan. This implies that the fault plane is of very low strength.

The geometry of and the abnormal sense of slip on the ISTL suggest that the present-day ISTL was not newly born under the Pliocene-Quaternary stress fields. Instead, this fault zone is likely to have inherited its geometry from the normal fault, which formed the Northern Fossa Magna basin in middle Miocene time by stretching the crust for at least $42 \mathrm{~km}$ (Sato et al., 2004). It should be noted that this normal fault has reactivated after a long period ( $\sim 10 \mathrm{My})$ of quiescence but is still of very low strength.

Acknowledgments. We thank a seismic crew of JGI for data ac- quisition. The Ministry of Education, Culture, Sports, Science and Technology, Japan financially supported the seismic and gravity surveys. The final version of this manuscript benefited from thorough and constructive reviews by Ramon Carbonell and two anonymous reviewers.

\section{References}

Furuse, N. and Y. Kono, Slab residual gravity anomaly: Gravity reduction due to subducting plates beneath the Japanese Islands, J. Geodynamics, 36, 497-514, 2003.

Hagiwara, Y., Analyses of gravity values in Japan, Bull. Earthq. Res. Inst., 45, 1091-1228, 1967.

Hagiwara, Y., N. Yamashita, T. Kosaka, K. Yano, and T. Yasui, Gravity observations along the Itoigawa-Shizuoka Geotectonic Line (I): An evaluation of the Bouguer anomaly in the Matsumoto Basin, Nagano Prefecure, Central Japan, Bull. Earthq. Res. Inst., Univ. Tokyo, 61, 537-550, 1986 (in Japanese).

Ikami, A., T. Yoshii, S. Kubota, Y. Sasaki, A. Hasemi, T. Moriya, H. Miyamachi, R. S. Matsu'ura, and K. Wada, A seismic-refraction profile in and around Nagano Prefecture, central Japan, J. Phys. Earth, 34, 457474, 1986.

Ikeda, Y. and T. Kumamoto, Shallow subsurface geometry of Active faults along the Itoigawa-Shizuoka Tectonic Line, central Japan, determined from closely spaced gravity survey, EOS (Transactions), 75, 674, 1994.

Ikeda, Y. and N. Yonekura, Determination of late Quaternary rates of net slip on two major fault zones in Central Japan, Bull. Dept. Geography, Univ. Tokyo, 18, 49-63, 1986.

Ikeda, Y., T. Imaizumi, M. Togo, K. Hirakawa, T. Miyauchi, and H. Sato (eds.), Atlas of Quaternary Thrust Faults in Japan, 254 pp., Univ. of Tokyo Press, Tokyo, 2002 (in Japanese)

Kato, H., Fossa Magna-A masked border region separating southwest and northeast Japan, Bull. Geol. Surv. Japan, 43, 1-30, 1992.

Kono, Y., Gravity anomalies well correlated with geological structures in central Japan: Conrad-Moho-slab residual Bouguer anomalies (CMS RAB), Chikyu (Earth Monthly), 25, 953-960, 2003 (in Japanese).

Kumamoto, T. and Y. Ikeda, Fault geometry and net slip of low angle thrust faults in the Kofu basin, central Japan, Zisin (J. Seism. Soc. Japan), 46, 245-258, 1993.

Matsuta, N., Structure and Behavior of the Itoigawa-Shizuoka Tectonic Line, Central Japan, in Quaternary Time: Partitioning of Slip on an Oblique-Slip Fault Zone, PhD Thesis, 155 p., Univ. Tokyo, 2002.

Ogawa, Y., S. Takakura, and Y. Honkura, Resistivity structure across Itoigawa-Shizuoka tectonic line and its implications for concentrated deformation, Earth Planets Space, 54, 1115-1120, 2002.

Okubo, S., Y. Ikeda, T. Kumamoto, G. Seta, N. Matsuta, H. Chiba, and Y. Arai, 2-D and 3-D subsurface density structure in the northern part of the Itoigawa-Shizuoka Tectonic Line derived by gravity surveying, J. Geod. Soc. Japan, 46, 177-186, 2000 (in Japanese with English abstract).

Okumura, K., Paleoseismology of the Itoigawa-Shizuoka tectonic line in central Japan, J. Seismol., 5, 411-431, 2001.

Sagiya, T., T. Nishimura, Y. Iio, and T. Tada, Crustal deformation around the northern and central Itoigawa-Shizuoka Tectonic Line, Earth Planets Space, 54, 1059-1063, 2002.

Sato, H. and Y. Ikeda, Major fault systems in northern Honshu, Japan, Chikyu (Earth Monthly), 21, 569-575, 1999a (in Japanese).

Sato, H. and Y. Ikeda, Crustal structure and extensional tectonics in northern Honshu, Japan, Chikyu (Earth Monthly), 27, 135-141, 1999b (in Japanese).

Sato, H., T. Iwasaki, S. Kawasaki, Y. Ikeda, N. Matsuta, T. Takeda, N. Hirata, and T. Kawanaka, Formation and shortening deformation of a back-arc rift basin revealed by deep seismic profiling, central Japan, Tectonophysics, 388, 47-58, 2004 (submitted).

Yano, T., Late Cenozoic geohistory in the Northern Fossa magna Region, Central Japan, J. Sci. Hiroshima Univ., C9, 81-132, 1986.

Y. Ikeda (e-mail: ikeda@eps.s.u-tokyo.ac.jp), T. Iwasaki, H. Sato, N. Matsuta, and T. Kozawa 